\title{
Rainwater Harvesting (RWH) and Groundwater Potential as Alternatives Water Resources in Malaysia: A Review
}

\author{
Syafiqa Ayob ${ }^{1}$, and Siti Nazahiyah Rahmat ${ }^{2 *}$ \\ ${ }^{1}$ Postgraduate Student, Faculty of Civil and Environment Engineering, Universiti Tun Hussein Onn \\ Malaysia, 86400, Batu Pahat, Johor, Malaysia. \\ ${ }^{2}$ Senior Lecturer, Faculty of Civil and Environment Engineering, Universiti Tun Hussein Onn \\ Malaysia, 86400, Batu Pahat, Johor, Malaysia.
}

\begin{abstract}
Socio-economic growth at present exerting pressure on the capacity of water supply. Water has been harvested worldwide since antiquity, thus, it is essential to manage the potential available of natural water supplies in the catchment to save water for dry periods when the supply-demand gap is comparatively high. The overall aim of this paper is to present a general overview of rainwater harvesting system and groundwater, and their potential applications for daily use. Many countries have implement the rainwater harvesting system as a sustainable approach for supplementing their public water supply. In Malaysia, the guidelines for rainwater harvesting implementations was first created in 1999 and developed by time to time to attract users. By using the system, the main findings reveals that it has overcome several of water problem issues. Groundwater is another alternative water supply that can be counted. Research has found that the availability of groundwater in few states in Malaysiawas in freshwater category based on its hardness level results. Thus, conclusions and recommendations are drawn where the gaps exist and more research needs to be focussed.
\end{abstract}

\section{Introduction}

Demand on water resources has been increasing rapidly and the issue of supplying adequate water to meet social needs is one of the most significant challenges. Adopting the concept of conservation of water resources could help to cope with the global water shortage as well as mitigate flood[1]. Rainwater Harvesting (RWH) and groundwater are the sources that can be explored to meet the water shortage problem.

RWH has been the main source of water supplies since decades ago. It has been improved from time to time until it becomes more sophisticated to users. Previously, jar collection system was used and later converted to underground storage tank complete with a mesh filter for a better water quality results. There are several advantages of RWH system in which have been identified by a number of researchers[2-4]. To name a few, the system

*Corresponding author: nazahiya@uthm.edu.my 
can be used in aquifer replenishment, to delay the surface water runoff which is very useful to prevent the occurrence of flash flood sand erosion control. Generally, RWH is a process where rainwater will be collected, stored and used, similar as treated water. Table 1 shows the guidelines and principle for rainwater harvesting implementation in Malaysia since 1999.

Table 1. Guidelines and principle for rainwater harvesting implementation[6].

\begin{tabular}{|c|l|c|}
\hline No & \multicolumn{1}{|c|}{ Guidelines } & Year \\
\hline 1 & $\begin{array}{l}\text { Guidelines for Installing a Rainwater Collection and Utilization System } \\
\text { Ministry of Housing and Local Government }\end{array}$ & 1999 \\
\hline 2 & $\begin{array}{l}\text { Rainwater Harvesting: Guidebook on Planning and Design Department of } \\
\text { Irrigation and Drainage Malaysia }\end{array}$ & 2009 \\
\hline 3 & $\begin{array}{l}\text { Guideline on Eco-Efficiency in Water Infrastructure for public Buildings } \\
\text { in Malaysia }\end{array}$ & 2011 \\
\hline 4 & $\begin{array}{l}\text { Urban Storm water Management Manual for Malaysia, MSMA 2nd } \\
\text { Edition }\end{array}$ & 2012 \\
\hline 5 & $\begin{array}{l}\text { Panduan Pelaksanaan Inisiatif Pembangunan Kejiranan Hijau e-Sistem } \\
\text { Pengumpulan dan Penggunaan Semula Air Hujan }\end{array}$ & 2012 \\
\hline 6 & Garis Panduan Perancangan Kejiranan Hijau & 2012 \\
\hline 7 & Garis Panduan Sistem Pengumpulan dan Penggunaan Air Hujan & 2013 \\
\hline 8 & $\begin{array}{l}\text { Urban Storm water Management e Part 6: Rainwater Harvesting, } \\
\text { MS2526-6:2014 }\end{array}$ & 2014 \\
\hline
\end{tabular}

To meet the increasing water demand, the development of distant water resources is not always the best option. Groundwater can be an alternative water source to meet water demand especially in areas where the surface water resources have been developed to their limits. However, groundwater has not become a favorite because it is very costly and the quantification of water that can be extracted is different in every state depending on the geo-technological condition of the area [7].

\section{Water Issues in Malaysia}

In Malaysia, the source of water for daily use comes from treated water. Due to the growth of population and expansion of industrial and agricultural, the demand for water has increased manifold. The problems arise when the water is not sufficient to meet the demand or polluted [8]. Vast development in various sectors resulted in such impacts on high demand of clean water in some areas. In addition, climate change may be one of the contributors to the water supply problem[9-10]. It changes the availability, quantity and quality of the water resources, which will have impact on the whole cycle of water supply. Nowadays, Malaysia and other Southeast Asian countries receive very high intensities of rainfall during monsoon season[11]. In December 2014, the villagers in Kelantan and some parts of Terengganu faced water supply disruption after a water supply plant affected by the devastating floods. Tube wells were then built to supply clean water[12].

Apart from that, another event that is often associated with the shortage of water is El Nino. El Nino is a natural phenomenon occurs in Pacific Ocean when warm waters of the western coast of South America replace the colder nutrient rich waters and cause impacts on the weather patterns such increase in temperature between $0.5^{\circ} \mathrm{C}$ and $2^{\circ} \mathrm{C}$ and reduce the amount of rainfall [13]. Fig.1 shows the impact of El Nino in Malaysia (in circle) in 2015.The country experienced dry and warm conditions from June to August which had 
affected the water resources utilisation in some areas. This paper will shed light on how the RWH system and groundwater represent the best solutions among the numerous natural water supply sources available.

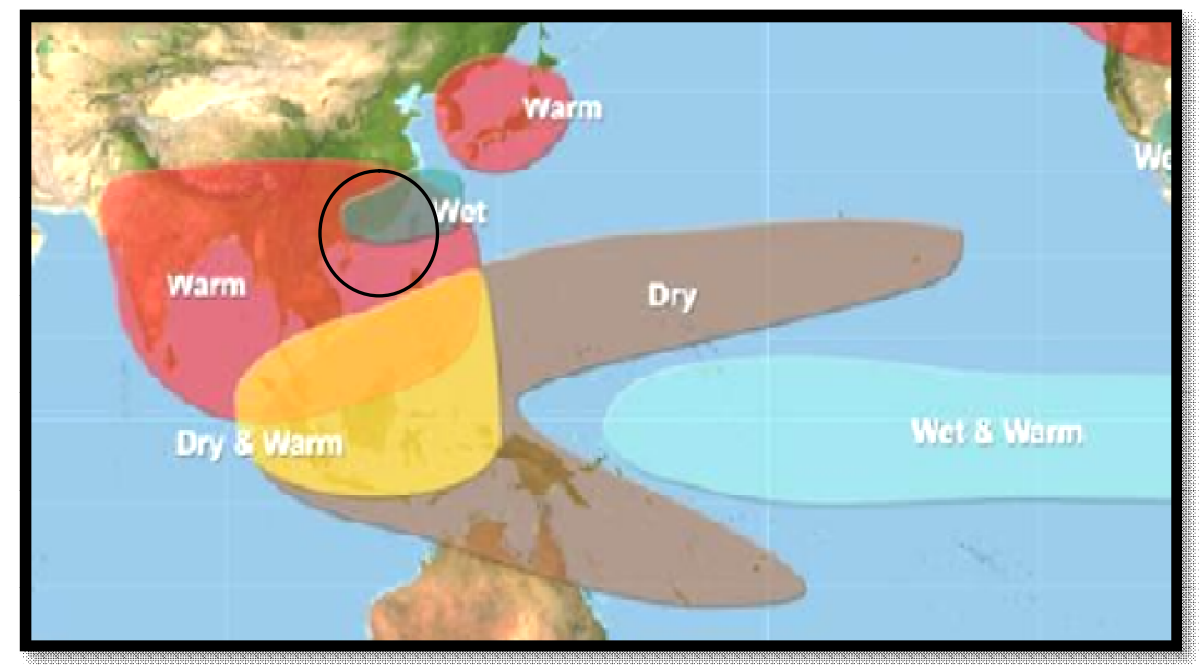

Fig.1. The impact of El Nino from June until August, 2015

\section{Rainwater harvesting and groundwater utilisation around the world}

\subsection{Rainwater Harvesting}

\subsubsection{South Asia - India}

Rainwater harvesting has become one of the recent trends as a sustainable approach for supplementing public water supply as well as for serving several other purposes. To control the wastage of water is one of the benefits of this system.RWH has been practiced as early as 4500 B.C. by the people of the United region. While the early water harvesting techniques used natural materials, $20^{\text {th }}$ centurytechnology has made it possible to use artificial means for increasing runoff from precipitation. Most of the cases in India, RWH systems being developed due to inadequate and unreliable water supply. People are resorting to rooftop water harvesting, which is the most convenient and economical water supply system. For instance, Aizawl city, located at the North East India has more than 10,000 rainwater harvesting tanks in individual houses [14]. In 2005, Vishwanath[15] reported the declination in ground water levels as well as the effects of pollution with nitrates which poses a threat to their colony. Two small tanks were built to collect rainwater and act as percolation tanks to recharge the aquifer. In addition, the second tank also accumulates the water recycled from sewage that has been treated physically and biologically. Both of these constructed tanks since then have supplied approximately about 2000 houses to their neighbourhood. 


\subsubsection{South East Asia- Japan, Thailand, Taiwan}

In Japan, the RWH techniques have been used both in public and private levels. The main sumo wrestling stadium, Kokugikan, rainwater runoff from the roof of $8400 \mathrm{~m}^{2}$ redirectedinto underground tanks $1000 \mathrm{~m}^{3}$ for non potable purposes[16]. Following the example of Kokugikan, new public facilities have begun to introduce a system of rain water usage in Tokyo. To meet the community demand, a simple and unique rainwater utilisation to utilise rainwater collected from the roof of private houses has been set up by local residents in the Mukojima district of Tokyo. To date, about 750 private and public buildings in Tokyo have introduce drain water collection and utilisation systems[14].

RWH techniques introduced by Thailand government called 'Thai Jar Programme' is shown in Fig. 2. The Government of Thailand initiated this programme in the 1980s with the aim to provide an alternative and supplementary water supply in rural areas with emphasis on self sufficiency and conservation[17]. A study on rainwater quality was conducted in north-east Thailand and concluded that rainwater is the safest and most economical source of drinking water in the region with no major health implications to users, as compared to the highly contaminated conventional water sources[17].In Taiwan, under its Ministry of Economic Affairs, a registered agency named Water Resources Bureau (WRB) has been developed. WRB came out with an idea in giving priority to the agricultural sector and subsidies to install a RWH system for gardening. This project has benefited more than 3000 farmers[14].

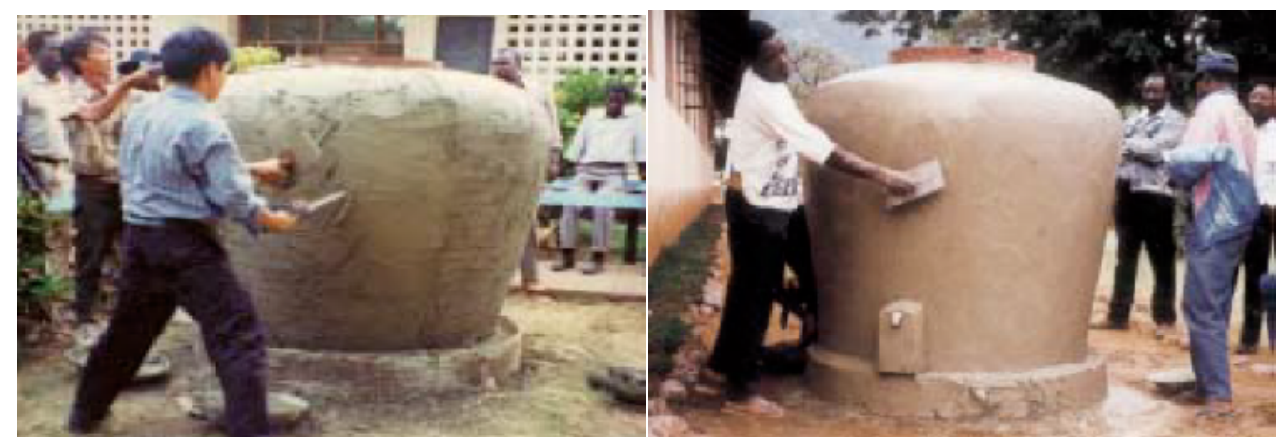

Fig. 2. Construction of 2,000-litre cement rainwater jar

\subsubsection{Malaysia}

The water crisis that occurred around 1998 is a starting move in implementing the RWH system in Malaysia. The 'Guidelines for Installing Rainwater Collection and Utilization System' 1999 was a preliminary approach of rainwater harvesting policy issued by the government of Malaysia[18]. The main purpose of the guidelines is to reduce the dependence on treated water and provides convenient buffer in times of emergency or a shortfall in the water supply. Construction of mini dams or rainwater tanks in urban area has been proposed[19]. In 2004, the Ministry of Housing and Local Government prepared another paper to the National Water Resources Council to encourage government buildings to install a rainwater collection system[20]. In 2006, Ministry of Energy, Water and Telecommunication (KTAK) came out with two new water related laws; Water Services Industry Act 2006 and Water Services Commission Act2006. However, RWH system is still not well received by Malaysian, especially in the residential areas, due to lack of awareness and they are not exposed to the advantages of using this system. 


\subsection{Groundwater}

Ground water is basically a renewable resource, however, the volume of water stored may vary greatly from place to place depending on physiography, climate, hydrogeology and rate of groundwater withdrawal used[21]. May and Mazlan [22]reported that approximately $18,184 \mathrm{~m}^{3}$ of water per day is obtained from the aquifer to supply to the steel factory near Langat river in Malaysia. As surface water sources fail to meet the rising demands of water supply in urban areas, groundwater reserves are being tapped and over-exploited resulting into decline in ground water levels and deterioration of ground water quality. This precarious situation needs to be rectified by immediately recharging the depleted aquifers[23].Based on Segal[24], groundwater quantification can be determined by using these three (3) methods which are groundwater model, pumping test and flow model. Groundwater recharge is a category of planned potable reuse. The two main types of groundwater recharge are called surface spreading and direct injection. The difference between direct injection and surface spreading is the way of water being collected and treated. For spreading surface, the water will be stagnant in the reclamation plant and eventually seep through the soils layers such as rock, gravel and clay to the earthen basins. This kind of recharge allow the recycled water to undergo further physical, biological, and chemical purification as it filters through the soil and ultimately becomes part of the groundwater system. For direct injection method, the collected water goes through additional treatment process. For example, water that is near the sea will be treated to desalinate the salt in water. The treated water is then re-injected into the ground. In Nepal, Yi et al.[11] have found that their study area has shallow groundwater level, thus they have come up with an idea to recharge the groundwater incorporate with rainwater harvesting system. While in other cases, they have come out with the idea to overcome the flat area problems with a technique called artificial recharge. This technique is a simple concept in which water is stored in subsurface permeable aquifers when water is plentiful and being extracted during times of peak.

\subsubsection{Potential Groundwater in Malaysia}

Groundwater in Malaysia is an important source which can meet the increasing demand of fresh water for a variety of uses [25]. Though groundwater has been used for centuries, usage is limited to shallow unconfined aquifers using excavate dwells [26]. In Malaysia, deep tube wells in the rough sand aquifer was first developed in the past 30years for water supply of coastal cities such as Kota Bharu [27]. Along with the water shortage problems in Selangor that arise each year, government has taken the initiative to encourage many groundwater development projects. The categories of potential groundwater resources are listed in Table 2[28].

The $\mathrm{pH}$ value in the north side of Kelantan, Malaysia was slightly acidic ranged from 6.2 to 6.8 and also had low content of chloride [29]. Another successful study by Sapari et al. [30]conducted in Malacca and Selangor, where identification of quality and quantity in fractured met a sedimentary rocks found that the groundwater was in freshwater category based on its hardness level results. This study then concluded that the availability groundwater has benefited the development of industries in the west coast of Peninsular Malaysia. This resource has potential to be further exploited for water supply particularly to remote areas. 
Table 2. Categories of potential groundwater resources[28].

\begin{tabular}{|l|l|}
\hline \multicolumn{1}{|c|}{ Type of Soils } & \multicolumn{1}{c|}{ Features } \\
\hline - Alluvium (sand and gravel) & $\cdot$ Most productive \\
\hline - Limestone & $\cdot$ Found in developed areas \\
\hline - Fractured sandstone & $\cdot$ Has equivalent metamorphic \\
\hline - Fractured igneous rock & $\cdot$ Least productive \\
\hline
\end{tabular}

\subsubsection{Rainwater for recharging groundwater}

Rainwater recharge methods widely used in country which receives tons of rainfall[16, 2730]. However, the decision whether to store or recharge water depends also on the rainfall pattern of a particular region where in average total quantity of rain water that can be used from the rooftop collection in normal monsoon season is about $70 \%$ to $90 \%[23,33]$. India is the best example in implementing this technique. In Mumbai, at least three quarters of the city's surface covered in hard concrete by way of buildings and road[35]. In2011, Water Aid report discussed the importance of managing grain water in order to recharge groundwater sources in Nepal. The aim of this report was to investigate the potential recharge zone, volumetric agumentation and the water quality of groundwater after being recharged. It was found that some areas can work as a reservoir where rainwater can be stored in monsoon and extracted in dry season. The water quality on analysis of physical, chemical and biological parameters assured safe with the reference of National Drinking Water Quality Standards (NDWQS) except for nitrate and fecal which was observed more in monsoon after harvesting than in pre-monsoon[36]. Apart from that, Bhavsar and Bhalge [37] claimed that the recharge techniques can be the best solution in the areas that having saline groundwater or water containing fluorides. In addition, Abdul et al., [38]did indicated that the recharge well system will $b$ successful when it is adopted to mitigate flood on site based on the physical model that has been developed.

\section{Conclusions and Recommendations}

Demand on water resources in Malaysia witnesses a substantial increase due to development, population increase, and global weather change. Adopting the concept of sustainability and conservation of water resources can help to cope with the global water shortage. Malaysia is blessed with an ample supply of water because of abundant rains. The only problem is lack of effective water resources management. Therefore, any attempt to manage water resources will have to take into account both the management of excess water (floods) and insufficient water (droughts). Based on this review the following conclusions can be drawn:

1. Water harvesting means making optimum use of rainwater to attain selfsufficiency in water supply, without being dependent on remote water sources.

2. In Malaysia, extended periods of droughts could cause water supply to fall short of water demands in states supporting large scale agriculture for rice production. This RWH system can be adopted to store the excessive water during wet season for later use (drought season).

3. Several water basins have shown high potential of groundwater. A comprehensive study needs to be carried out to explore potential area of groundwater in Malaysia for alternative to clean water resources. 
4. Many researchers have adopted rainwater harvesting techniques in different parts of the country to improve the groundwater quality. The only thing is that it has not been done systematically in all places. In Malaysia, this integrated approach has not been comprehensively studied and it is worthwhile to further investigate.

This study was supported by Fundamental Research Grant Scheme (FRGS) (Vote 1523).

\section{References}

[1] M.S. Adnan, N.C. Ali, Y. Erfen, S.N. Rahmat, M.A.M. Razi and S. Musa, Analysis the Impact of Bridges Existance for the Segamat River Using Infowork RS, IOP Conf. Ser. Mater. Sci. Eng., 136(1), (2016)

[2] M. Nasir, N. Othman, K. Azlan, M.F. Omar and E.H. Omar, Effectiveness of Rainwater Harvesting System At Office, Proc. 14th Int. Conf. Rain Water Catchment Syst. PWTC, KL, (2009)

[3] K.E. Lee, M. Mokhtar, M. Mohd Hanafiah, A. Abdul-Halim and J. Badusah, Rainwater harvesting as an alternative water resource in Malaysia: Potential, policies and development, J. Clean. Prod, 126, 218-222, (2015)

[4] S. Man, N. M. Hashim, A.H. Ahmad, M.T. Khin and N.S. Sidek, Kebolehupayaan sistem penuaian hujan sebagai bekalan air alternatif di Malaysia: Suatu penelitian awal, Geogr. Malaysian J. Soc. Sp., 10(6), 97-104, (2014)

[5] T.A. Mohammed, M.J. Megat Mohd Noorand A.H. Ghazali, Study on Potential Uses of Rainwater Harvesting in Urban Areas,Proc. Colloq. Rainwater Util., (2007)

[6] Y.M.A. Sharifuddin, S.S. Mohamed, N.H. Adnan and K.A. Musa,Kajian Kuantiti Dan Kualiti Air Hujan Sistem Penuaian Air Hujan (SPAH) Di Rumah Panjang Bair Betong,Inst. Penyelid. Hidraul. Kebangs. Malaysia, 1, 1-8, (2015)

[7] N. Weng, A Comparative Study Of Water Georgetown-Malaysia And Pattaya, Iranian J. Environ. Health Sci. Eng., 3, (2006)

[8] S.N. Rahmat, A.Z. Mohd Ali, M.H. Wan Ibrahim, N.A. Alias, Oil and grease (O\&G) removal from commercial kitchen waste water usingcarbonised grass as a key media, MATEC Web of Conferences, 87(01010), (2017)

[9] S.N. Rahmat, N. Jayasuriya, M. Bhuiyan and M.S. Adnan, Temporal Trends of Discrete Extreme Events - A Case Study, IOP Conf. Ser. Mater. Sci. Eng., 136(1), (2016)

[10]S. N. Rahmat, N. Jayasuriya and M. A. Bhuiyan, Short-term droughts forecast using Markov chain model in Victoria, Australia,(2016)

[11]Y. Yi, L. Billa and A. Singh, Geoscience Frontiers Effect of climate change on seasonal monsoon in Asia and its impact on the variability of monsoon rainfall in Southeast Asia, Geosci. Front., 6(6), 817-823, (2015)

[12]A.F. Rahim, Rakyat Kelantan gembira selepas 25 tahun 'menderita' hadapi masalah air,Utusan Online, Kelantan, (2016)

[13]J. Saimon, El Nino: The Good, Bad and the Ugly of 2015, (2015)

[14]P.S Mathur and M. Prashad, Rainwater Harvesting and Utilisation. UN-Habitat, United Nations Centre for Human Settlements, Book 2: Beneficiries \& Capacity Builders,Nairobi, Kenya, (2005)

[15]S. Vishwanath, Domestic Rainwater Harvesting Some applications in Bangalore, India, $1-5,(2005)$ 
[16]K.F.A. Lo, Multi-Faceted Use of Rainwater Harvesting To Combat Water Problems, XI IRCSA Conf., (1991)

[17]T.V. Luong, A construction manual for cement rainwater Jars and Tanks, Bangkok, Thailand, (2002)

[18]H.Y. Meng, F.T. Yong, N.M. Salleh, H. S. Seng, A.H.Md.Kassim, C. P. Siang, T.S. Tiat and K.Nantakumar, Guidelines for Installing A Rainwater Collection and Utilization System, Malaysia,(1999)

[19]H. Shawahid, A.R. Suhaimi, M.K. Rasyikah, S.A. Jamaluddin, Y.F. Huang and M.Farah, Policies and incentives for rainwater harvesting in Malaysia,Rainwater Utilization Colloquium, (2007)

[20]A.I.C. Ani, Rainwater Harvesting System Evaluation: A Resident Experience In Sabah,Malaysia, Int. Symp. Dev. Econ. Commonalities Among Divers., 26-39, (2009).

[21]P. Madhnure and S.K. Jain,Additional Ground Water Storage Potential for Artificial Recharge in Phreatic Aquifers of Yavatmal District, Maharashtra, India,Natl. Semin. Rainwater Harvest. Water Manag., 91-100, (2006)

[22] R.May and N.S.B. Mazlan, Numerical simulation of the effect of heavy groundwater abstraction on groundwater-surface water interaction in Langat Basin, Selangor, Malaysia, Enviromental Earth Sci., 71(3), 1239-1248, (2014)

[23] W. Struckmeier, Y. Rubin and J.A.A. Jones, Groundwater - reservoir for a thirsty planet?, $2^{\text {nd }}$ Edition, The Netherlands: International Year of Planet Earth, (2005)

[24]D. Segal, Singapore's Water Trade with Malaysia and Alternatives, John F.Kenedy School of Government, Harvard University,Singapore,(2004)

[25]A.A.F. Mohamed, W.Z. Wan Yaacob, M.R. Taha and Samsudin, Groundwater and Soil Vulnerability in the Langat Basin Malaysia, Eur. J. Sci. Res., 4, 628-635, (2009)

[26]N.K. Ang, Hydrologic Framework and Groundwater Resources Utilisation in Peninsula Malaysia,Proc. Groundwater Forum. No. 4, Geological Society of Malaysia, 1.1-1.5 (1994)

[27]B. Sofner, Groundwater Monitoring and Groundwater Protection in North Kelantan and Perlis, Malaysia. Hannover: Fed. Inst. of Geosciences and Natural Resources, (1989)

[28]E. Fahnline, The production and remediation of malaysia's groundwater resources,Ensearch Sustainability and Environmental Management Conf. and Exhibition, October, (2013)

[29] A.R. Samsudin, A. Haryono, U. Hamzah and A.G. Rafek, Salinity mapping of coastal groundwater aquifers using hydrogeochemical and geophysical methods: a case study from north Kelantan, Malaysia,Environ. Geol., 55(8), 1737-1743, (2008)

[30]N. Sapari, J. Raja Zainariah and H. Raja Azie, Quantity and Quality of Groundwater in Fractured Metasedimentary Rocks of the West Coast of Peninsular Malaysia,40(6), 537-542, (2011)

[31]A. Stringer and K. Nash, Design of Rainwater Harvesting Systems in Oklahoma,5, (2016)

[32]B. M. Mati, M. Malesu and A. Oduor, Promoting rainwater harvesting eastern and southern Africa, World Agroforestry Centre, Nairobi, Kenya, (2005)

[33]L.K. Bisoyi, Rain Water Harvesting - An ultimate need in 21st Century,Natl. Semin. Rainwater Harvest. Water Manag., 105-110, (2006)

[34] Y.A. Reddy, Water Harvesting : Limitations in Implementation,Natl. Semin. Rainwater Harvest. Water Manag., 70-77, (2006) 
[35] S.H. Deshmukh and R.B. Magar, The Scope of Rainwater Harvesting in Urban Areas, Natl. Semin. Rainwater Harvest. Water Manag., (2006)

[36] S.D. Shrestha, K. Rajbhandari, D.B. Singtan and S. Mishra, Rainwater harvesting for recharging shallow groundwater, A WaterAid Nepal, 41, (2011)

[37]C. Bhavsar and P. Bhalge, Roof Top Rain Water Harvest- A Long Lasting Solution to Drive away the Need of Water Tankers, Natl. Semin. Rainwater Harvest. Water Manag., (2006)

[38]L. Abdul, Q. Tunji, A.A.A.Latiff, D. Tjahjanto, and S. Akib, The effectiveness of groundwater recharges well to mitigate flood, 6(1), 8-14, (2011) 